\title{
APAKAH KONSUMEN RESTO HOTEL MENGETAHUI ISU FOOD WASTE?
}

\author{
Airana Nafira Ramadhita ${ }^{1 *}$, Meti Ekayani ${ }^{2}$, Sri Suharti ${ }^{3}$ \\ ${ }^{1}$ IImu Sumberdaya Alam dan Lingkungan Sekolah Pascasarjana, \\ IPB University, Bogor 16680, Indonesia \\ ${ }^{2}$ Departemen Ekonomi Sumberdaya Lingkungan, Fakultas Ekonomi dan Manajemen (FEM), \\ IPB University, Bogor 16680, Indonesia \\ ${ }^{3}$ Departemen IImu Nutrisi dan Teknologi Pakan, Fakultas Peternakan (Fapet), \\ IPB University, Bogor 16680, Indonesia
}

*)E-mail: airana.nr23@gmail.com

\begin{abstract}
Abstrak
Konsep prasmanan pada restoran hotel merupakan salah satu faktor penyebab timbulnya food waste, hal ini didasarkan karena adanya perbedaan preferensi konsumen dalam menentukan jenis dan porsi makanan. Penelitian ini bertujuan untuk menganalisis karakteristik dan pengetahuan objektif konsumen resto hotel terhadap isu food waste. Penelitian ini menggunakan pendekatan eksploratori kuantitatif dengan desain cross sectional study. Penelitian ini melibatkan 363 mahasiswa dan pekerja yang pernah mengunjungi restoran hotel berkonsep prasmanan yang dipilih menggunakan teknik snowball sampling. Lokasi penelitian dilakukan di Hotel Amaris, Kota Bandung. Sampel limbah dan komposisi makanan diambil dengan menggunakan metode pengumpulan dan analisis berdasarkan SNI 1903964-1994. Kuesioner dalam bentuk Google Form didiseminasi melalui WhatsApp Group. Selanjutnya, data penelitian dianalisis secara deskriptif menggunakan tabulasi dan grafik. Hasil kajian menunjukkan, hanya sebagian responden yang mengetahui isu food waste. Hasil penelitian ini dapat menjadi dasar pertimbangan pihak pemangku kebijakan serta penelitian lanjutan dalam meningkatkan pengetahuan terkait food waste kepada konsumen untuk mencegah timbulnya food waste di resto hotel.
\end{abstract}

Kata kunci: food waste, konsumen, pengelolaan, prasmanan, resto hotel

\section{Do Restaurant Hotel Consumers Know about Food Waste Issue?}

\begin{abstract}
The buffet concept at the hotel restaurant is one of the factors causing food waste, and this is based on differences in consumer preferences in determining the type and portion of food. This study aims to analyze the characteristics and objective knowledge of hotel restaurant consumers on food waste. This study used a quantitative exploratory approach with a cross sectional study design. This study involved 363 students and workers who had visited the hotel restaurant with the buffet concept selected using the snowball sampling technique. The research location was conducted at the Amaris Hotel, Bandung City. Waste samples and food composition were taken using collection and analysis methods based on SNI 1903964-1994. The questionnaire in the form of Google Forms was disseminated through the WhatsApp Group. Furthermore, the research data were analyzed descriptively using tabulations and graphics. The study results showed that only some respondents know the issue of food waste. This study's results can be a basis for policymakers' consideration and further research in increasing knowledge related to food waste to consumers to prevent food waste in hotel restaurants.
\end{abstract}

Keyword: buffet, consumer, food waste, hotel restaurant, management

\section{PENDAHULUAN}

Penyebab timbulnya food loss and waste dapat ditemukan dari tingkat produksi hingga konsumsi (FAO, 2011). Pada tingkat konsumsi, pengetahuan konsumen merupakan salah satu faktor yang berperan dalam menentukan perilaku konsumen. Pengelolaan food loss and waste dipayungi oleh konsep Sustainable Development Goals (SDGs) yang secara khusus dielaborasi pada poin ke 12.3. Poin ini memastikan pola konsumsi dan produksi yang berkelanjutan salah satunya dengan cara menghimbau masyarakat global mengurangi setengah per kapita food waste pada tingkat ritel dan konsumen di tahun 2030. Salah satu sumber timbulan sampah makanan berasal dari sektor wisata dan Kota Bandung merupakan salah satu destinasi pariwisata yang memiliki Indeks Pariwisata tertinggi di Indonesia (95,30\%) berdasarkan pengukuran Frontier 
Consulting Group dan Tempo Media Grup (Pemerintah Provinsi Jawa Barat, 2018). Hotel merupakan penunjang pariwisata yang menyediakan jasa akomodasi serta penyediaan jasa makanan dan minuman. Kegiatan ini berdampak pada produksi timbunan sampah makanan. Berdasarkan penelitian di Kota Bandung, timbunan sampah makanan ditemukan paling banyak di hotel, yang didominasi sisa bahan atau sisa makanan dan dapat dipengaruhi oleh konsep prasmanan pada restoran hotel (Brigita \& Rahardyan, 2013).

Menurut Aktas et al. (2018), konsumen merupakan kontributor signifikan terhadap food waste karena memiliki berbagai macam perilaku yang dapat memengaruhi tingkat food waste yang diproduksi. Adapun perilaku konsumen dapat dipengaruhi oleh pengetahuan konsumen mengenai isu food waste. Apabila mengacu pada konsep Food Recovery Hierarchy oleh US EPA (2017) terkait pemulihan makanan, pilihan konsumen untuk mengurangi jumlah makanan yang dikonsumsi merupakan langkah yang paling disarankan. Selain itu, penelitian mengenai tingkat pengetahuan konsumen dapat memberikan pemahaman mengenai persepsi perilaku food waste (Fox et al., 2018).

Beberapa penelitian sebelumnya yang membahas mengenai karakteristik responden serta kecenderungan seseorang menyisakan makanan, memberikan simpulan bahwa bentuk informasi terkait dengan isu food waste dapat mendorong seseorang mengurangi food waste behaviour. Saran yang diberikan untuk mengubah food waste behavior pada tingkat rumah tangga adalah dengan memberikan informasi berupa kampanye mengenai food waste yang dihubungkan dengan kebiasaan rutinitas rumah tangga (Stancu, Haugaard, dan Lähteenmäki, 2016).

Selain itu, Lavén (2017) menyatakan bahwa pemasaran oleh pihak hotel kepada konsumen mengenai kesadaran terhadap isu food waste serta dampaknya yang ditimbulkan dapat mengubah perilaku konsumen mengurangi food waste. Pada penelitian Fox et al. (2018) yang mengukur tingkat pengetahuan pada kelompok pemuda di empat negara termasuk Indonesia, meningkatkan pengetahuan objektif terkait dengan food waste perlu dilakukan dalam rangka mencegah timbunan makanan yang berlebihan.

Penelitian sebelumnya yang dilakukan oleh Jereme et al. (2018) dan Schanes et al. (2018) lebih banyak membahas mengenai karakteristik penyumbang food waste dari sektor rumah tangga. Selain itu, masih minim penelitian yang membahas mengenai pengetahuan objektif serta karakteristik pada tingkat konsumen, khususnya konsumen pada resto hotel. Pada penelitian ini, dilakukan survei terhadap pengetahuan objektif mendasar pada konsumen mengenai isu food waste, sebagai dasar pertimbangan untuk mencegah serta mengelola food waste yang timbul di resto hotel. Berdasarkan hal tersebut, penelitian ini bertujuan untuk (1) menganalisis jumlah dan komposisi food waste konsumen resto hotel; (2) mengidentifikasi faktor yang dapat mendorong konsumen mengurangi food waste; dan (3) menganalisis pengetahuan objektif food waste pada konsumen resto hotel.

\section{METODE}

Penelitian ini menggunakan desain crosssectional study. Lokasi penelitian yang dipilih yaitu di Hotel Amaris Setiabudhi di Kota Bandung, dengan pertimbangan bahwa Kota Bandung merupakan kota dengan indeks pariwisata tertinggi di Jawa Barat menurut Pemprov Jawa Barat (2018) dan memproduksi sampah makanan $316.8 \mathrm{~m} 3 /$ hari menurut BPS Kota Bandung (2017).

Penelitian ini menggunakan jenis data primer dan sekunder. Data primer dikumpulkan melalui observasi, survei menggunakan kuesioner daring, dan wawancara mendalam (in-depth interview). Data primer meliputi data jumlah food waste di resto hotel, karakteristik serta pengetahuan responden mengenai food waste dan upaya pengelolaan food waste pada resto hotel. Pengambilan data penelitian dilakukan pada Maret 2020 sampai September 2020.

Metode pengumpulan data dan analisis food waste berdasarkan metode pengambilan dan pengukuran contoh timbulan dan komposisi sampah perkotaan yang dikeluarkan oleh Badan Standardisasi Nasional (1994). Pengambilan data food waste dilakukan selama delapan hari berturut-turut untuk merepresentasikan dua tren sampah di hari kerja dan akhir pekan (puncak musim). Penggunaan panduan SNI 1903964-1994 dipilih sebagai metode yang terstandar secara nasional. Sisa makanan pada piring konsumen dipilah per komponen setiap harinya dan ditimbang. Seluruh komponen dihitung dan hasilnya di rata-rata per hari kerja dan akhir pekan. Sebagai catatan penting, pengambilan data dilakukan seminggu sebelum situasi tanggap darurat pandemi Covid-19. 
Data responden konsumen resto hotel dikumpulkan melalui kuesioner yang disusun menggunakan Google Forms dan didiseminasi melalui WhatsApp Group. Populasi penelitian ditujukan pada konsumen resto hotel secara umum sebagai pengganti pengambilan contoh insidental yang dibatasi pada situasi tanggap pandemi Covid-19.

Jumlah responden sebanyak 363 yang dipilih mendekati jumlah konsumen pada resto hotel (440 responden). Teknik pengambilan contoh responden menggunakan metode snowball sampling kepada kelompok pekerja dan mahasiswa selama dua minggu. Pemilihan kelompok responden sesuai dengan batasan umur kepemilikan kartu tanda penduduk sebagai persyaratan registrasi hotel. Skala Guttman (ya/tidak) digunakan pada kuesioner dan dilanjutkan dengan beberapa pilihan jawaban yang dapat mendukung untuk mengeksplorasi preferensi konsumen.

Data kuesioner dianalisis secara deskriptif kuantitatif menggunakan tabulasi dan grafik. Diagram lingkaran (pie chart) yang digunakan menunjukkan persentase respons terbanyak yang dipilih oleh konsumen dalam merepresentasikan preferensinya. Selanjutnya, pengetahuan responden terhadap isu food waste dianalisis melalui rata-rata dan standar deviasi jawaban yang dipilih. Adapun wawancara in-depth dengan pihak manajemen hotel dilakukan secara daring untuk mengetahui upaya pengelolaan serta pencegahan food waste yang dilakukan oleh resto hotel. Alat yang digunakan dalam mengolah dan menganalisis data penelitian adalah Microsoft Excel.

\section{HASIL}

\section{Jumlah dan Komposisi Food Waste}

Data food waste diperoleh dari sisa makanan pada piring konsumen di Hotel Amaris Setiabudhi. Secara teknis penghitungan food waste langsung dipisahkan per komponen setelah konsumen meninggalkan area resto hotel. Rata-rata timbulan food waste dikelompokkan pada hari kerja dan akhir pekan. Hari Sabtu dan Minggu merupakan akhir pekan dengan rata-rata jumlah pengunjung pada restoran hotel mencapai lebih dari dua kali lipat dibandingkan hari kerja. Hasil dari penghitungan rata-rata food waste dan pengunjung pada hari kerja dan akhir pekan disajikan pada Gambar 1.

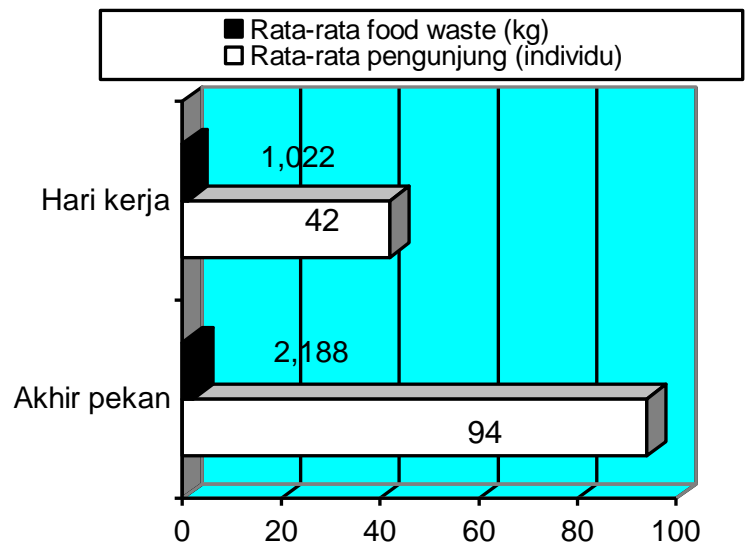

Gambar 1 Rata-rata pengunjung dan food waste di resto hotel

Berdasarkan data yang diperoleh, rata-rata jumlah pengunjung resto pada akhir pekan dibandingkan pada hari kerja mencapai lebih dari dua kali lipat. Perbandingan ini selaras dengan rata-rata timbulan food waste yang dihasilkan. Dugaan pada penelitian ini, faktor yang memengaruhi rata-rata food waste adalah jumlah pengunjung resto hotel. Adapun perbedaan jumlah pengunjung pada hari kerja dan akhir pekan didasarkan pada tujuan berkunjung. Pengunjung di hari kerja didominasi oleh karyawan dengan tujuan bekerja ataupun menghadiri lokakarya, sedangkan pada akhir pekan pengunjung didominasi oleh keluarga dengan tujuan berwisata.

Pengelompokan komponen food waste dilakukan untuk mengetahui komposisi makanan yang lebih banyak terbuang oleh konsumen. Komponen makanan dibagi menjadi sembilan kelompok makanan berdasarkan tipe hidangan yang disajikan oleh hotel (Gambar 2).

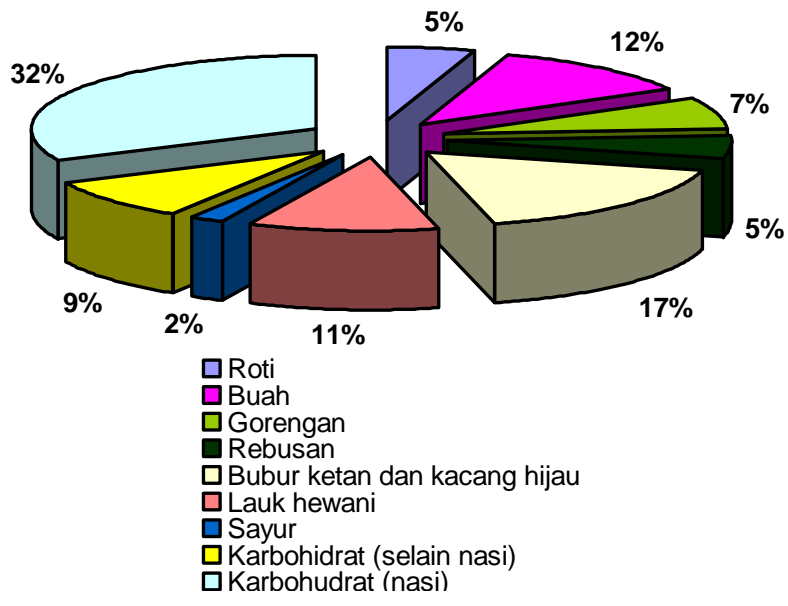

Gambar 2 Persentase food waste per jenis makanan 
Tabel 1 Sebaran responden berdasarkan karakteristik sosial ekonomi

\begin{tabular}{|c|c|c|c|}
\hline \multirow[b]{2}{*}{ Variabel } & \multirow[b]{2}{*}{ Kategori } & \multicolumn{2}{|c|}{ Responden } \\
\hline & & $\begin{array}{c}\mathrm{n} \\
\text { (jumlah) }\end{array}$ & $\begin{array}{c}\% \\
\text { (Persentase) }\end{array}$ \\
\hline \multirow{2}{*}{$\begin{array}{l}\text { Jenis } \\
\text { kelamin }\end{array}$} & Laki-laki & 118 & 33 \\
\hline & Perempuan & 245 & 67 \\
\hline \multirow[t]{4}{*}{ Umur } & $\begin{array}{l}<18-25 \\
\text { tahun }\end{array}$ & 72 & 20 \\
\hline & $\begin{array}{l}26-35 \\
\text { tahun }\end{array}$ & 131 & 36 \\
\hline & $\begin{array}{l}36-45 \\
\text { tahun }\end{array}$ & 82 & 23 \\
\hline & $>45$ tahun & 78 & 21 \\
\hline \multirow{4}{*}{$\begin{array}{l}\text { Tingkat } \\
\text { pendidikan } \\
\text { terakhir }\end{array}$} & SMP/SMA & 29 & 8 \\
\hline & D3/S1 & 233 & 64 \\
\hline & S2 & 92 & 25 \\
\hline & S3 & 9 & 2 \\
\hline \multirow{4}{*}{$\begin{array}{l}\text { Pendapatan } \\
\text { per bulan }\end{array}$} & $<2$ juta & 69 & 19 \\
\hline & 2-5 juta & 99 & 27 \\
\hline & 6-10 juta & 82 & 23 \\
\hline & $>10$ juta & 113 & 31 \\
\hline \multirow{2}{*}{$\begin{array}{l}\text { Bidang } \\
\text { pekerjaan }\end{array}$} & Lingkungan & 111 & 31 \\
\hline & Lainnya & 252 & 69 \\
\hline \multirow{5}{*}{$\begin{array}{l}\text { Dominasi } \\
\text { tingkat hotel }\end{array}$} & Bintang 1 & 20 & 5 \\
\hline & Bintang 2 & 20 & 6 \\
\hline & Bintang 3 & 132 & 36 \\
\hline & Bintang 4 & 159 & 44 \\
\hline & Bintang 5 & 32 & 9 \\
\hline \multirow{3}{*}{$\begin{array}{l}\text { Tujuan } \\
\text { menginap }\end{array}$} & Berlibur & 194 & 55 \\
\hline & Bekerja & 153 & 43 \\
\hline & Lainnya & 19 & 2 \\
\hline
\end{tabular}

Pada penelitian ini, jenis karbohidrat dipisahkan menjadi dua kelompok, yakni karbohidrat berbahan dasar nasi (nasi putih, nasi goreng, bubur, dan ketupat) dan karbohidrat selain nasi seperti mie, dan bihun. Berdasarkan hasil pengamatan, komponen makanan yang paling banyak terbuang adalah karbohidrat berbahan dasar nasi (32\%). Dari seluruh komponen food waste, bubur ayam memberikan massa yang dominan karena adanya cairan pada proses pemasakan.

Setelah bubur ayam, jenis hidangan yang terbuang setiap harinya adalah nasi goreng dan nasi putih. Sebagai makanan pokok, ketiga jenis hidangan ini tersedia di resto hotel setiap hari selama pengambilan data. Selain itu, salah satu makanan yang ditemukan terbuang hampir setiap harinya adalah roti yang gosong. Penyebab dari roti yang gosong adalah ketidaktahuan atau kurangnya keterampilan konsumen hotel dalam mengoperasikan alat pembakar roti.

\section{Sosio-Demografi Responden Pengunjung Hotel}

Survei secara umum terhadap konsumen yang pernah mengunjungi resto hotel dengan konsep prasmanan dilakukan selama dua minggu. Kuesioner dibagi menjadi lima bagian, yakni konsep prasmanan hotel, alasan konsumen menyisakan makanan, upaya pengurangan food waste di resto hotel, pengetahuan mengenai food waste, dan karakteristik responden secara demografi. Karakteristik sosio-demografi responden pada Tabel 1 didasari oleh beberapa penelitian terdahulu yang menguji hubungan antara karakteristik responden dan timbulan food waste.

Selama periode penyebaran kuesioner, didapatkan respons sebanyak 363 responden yang didominasi oleh wanita. Kelompok usia terbanyak adalah rentang 26-35 tahun (36\%) dengan latar belakang pendidikan D3 dan S1 (64\%). Responden paling banyak memiliki pendapatan per bulan lebih dari Rp10.000.000,00 dengan mayoritas bekerja di bidang pekerjaan yang tidak berhubungan dengan lingkungan. Sebagai pertimbangan, tingkat bintang hotel yang paling banyak dihuni oleh responden didominasi pada hotel berbintang 4 . Tujuan responden menginap di hotel untuk berlibur lebih banyak dipilih dibandingkan untuk bekerja dan alasan lainnya (seminar).

\section{Konsep Prasmananan Resto Hotel}

Pada bagian pertama, responden diberikan pertanyaan mengenai konsep prasmanan di resto hotel. Hanya sebagian kecil responden (2\%) yang tidak menyukai konsep prasmanan, sedangkan sisanya menyukai konsep prasmanan. Beberapa alasan yang paling banyak dipilih dalam menyukai konsep prasmanan adalah dapat mengatur kuantitas makanan atau porsi yang diambil (39\%), diikuti dengan banyaknya variasi menu (30\%), konsep hidangan langsung atau bisa melihat live menu $(17 \%)$, dan bisa mencicip makanan terlebih dahulu (13\%). Respons lainnya meliputi alasan menghemat waktu, bersosialisasi dengan tamu lainnya, merasa konsep prasmanan menambah nilai menginap di hotel, serta penggunaan alat makan yang reusable yang ramah lingkungan sekaligus lebih praktis bagi responden.

\section{Alasan Konsumen Menyisakan Makanan}

Pertanyaan selanjutnya terkait dengan kebiasaan menyisakan makanan di piring. Di dalam pengantar kuesioner telah dijelaskan 
definisi food waste yang digunakan pada penelitian ini yaitu sisa konsumsi pada piring konsumen. Penghitungan tidak termasuk bagian hidangan yang jarang atau tidak dapat dikonsumsi. Hasil survei menunjukkan rasio antara konsumen yang menjawab pernah menyisakan makanan yang sudah diambil dengan yang tidak menyisakan makanan adalah 1:2.

Kombinasi alasan yang diberikan pada penelitian ini merupakan alasan yang mendorong timbulnya food waste baik dari pihak produsen maupun konsumen. Alasan yang berhubungan dengan produsen meliputi kondisi makanan yang buruk serta proses pemasakan yang tidak sempurna. Sedangkan untuk alasan dari sisi konsumen meliputi terlalu banyak mengambil porsi dan tidak cukup waktu dalam menghabiskan makanan yang diambil. Adapun rasa makanan yang kurang cocok adalah gabungan dari preferensi konsumen serta pemenuhan ekspektasi konsumen oleh produsen. Dari 144 responden yang menjawab pernah menyisakan makanan, didapatkan tiga alasan terbesar dalam menyisakan makanan yaitu rasa makanan yang kurang cocok; terlalu banyak mengambil porsi makanan; dan waktu yang kurang dalam menghabiskan makanan (Gambar 3).

Alasan rasa makanan yang kurang cocok mencapai hampir setengah dari alasan lainnya (44\%). Hasil ini menunjukkan, adanya kesenjangan antara pemenuhan ekspektasi konsumen dengan kapasitas penyajian menu oleh hotel. Seringkali konsumen memiliki standar cita rasa sebuah hidangan tertentu sebelum memilih makanan, dan adanya kemungkinan rasa yang tidak sesuai dengan ekspektasi dapat menimbulkan food waste.

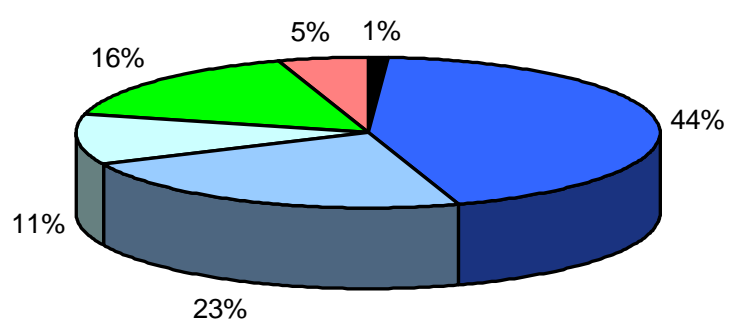

\footnotetext{
- Lainnya

$\square$ Rasa makanan kurang cocok

$\square$ Terlalu banyak mengambil porsi

$\square$ Proses pemasakan tidak sempurna

$\square$ Tidak cukup waktu

$\square$ Kondisi makanan buruk
}

Gambar 3 Sebaran responden berdasarkan alasan menyisakan makanan

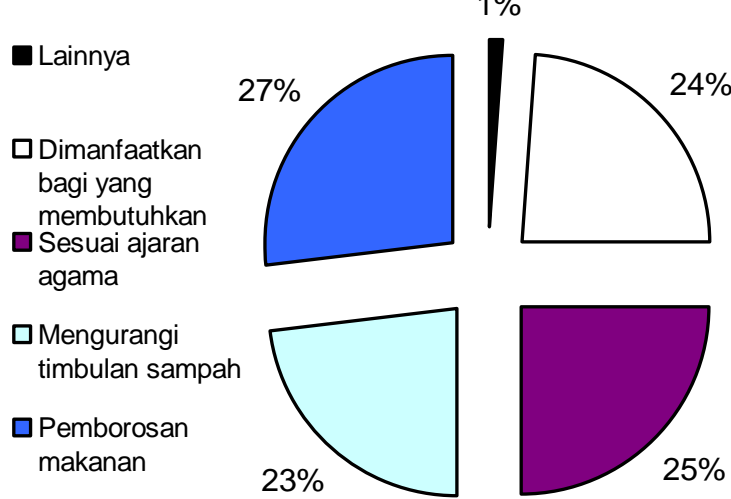

Gambar 4 Sebaran responden berdasarkan pendekatan pengurangan food waste

Lebih lanjut, alasan lainnya yang menyebabkan konsumen menyisakan makanan dikarenakan makanan yang dikonsumsi mengandung alergen. Terkait alasan ini, penyisaan food waste tidak dapat dihindari dan perlu adanya masukan kepada pihak resto hotel untuk menyediakan makanan khusus bagi konsumen yang memiliki alergi pada makanan. Opsi tersebut dapat diberikan pada saat registrasi pengunjung hotel untuk memudahkan manajemen hotel dan konsumen untuk mencegah adanya food waste.

Tidak cukup waktu merupakan alasan yang cukup banyak dipilih (17\%). Alasan ini menunjukkan kurangnya kemampuan responden dalam mengelola waktu dalam berkegiatan di hotel, khususnya pada saat waktu makan. Kemungkinan lainnya adalah pengunjung hotel tidak memprioritaskan waktu makan sebagai bagian dari tujuannya berkegiatannya di hotel. Terakhir, responden diminta mengingat komposisi makanan apa yang paling sering disisakan, dan hasilnya didominasi oleh pilihan nasi atau karbohidrat.

\section{Upaya Mengurangi Timbunan Food Waste di Resto Hotel}

Pada bagian ketiga, responden diberikan pertanyaan mengenai upaya pengurangan food waste di resto hotel (Gambar 4). Pertanyaan pertama berkaitan dengan peran yang dimiliki oleh konsumen dalam pengurangan food waste di resto hotel. Sebanyak 295 responden $(80 \%)$ merasa memiliki peran dalam pengurangan food waste dan 97 persen bersedia mengurangi food waste. Apabila bersedia, maka pertanyaan selanjutnya adalah alasan yang relevan bagi responden dalam mengurangi food waste. Empat alasan yang diberikan merupakan 
representasi dari empat pendekatan dalam mengurangi timbulan food waste yakni pendekatan ekonomi (pemborosan makanan), agama (sesuai ajaran agama), sosial (dapat dimanfaakan bagi yang membutuhkan), serta lingkungan (mengurangi timbunan sampah).

Seluruh responden yang bersedia mengurangi food waste memilih keempat alasan dengan persentase yang hampir sama. Alasan terbanyak yang dipilih responden adalah pendekatan ekonomi (27\%), diikuti oleh agama (25\%). Beberapa alasan yang ditambahkan oleh responden diklasifikasi oleh peneliti ke dalam pendekatan yang masih relevan. Beberapa contohnya adalah "mubazir", "perlu mensyukuri nikmat Allah", "mengikuti hadits nabi" yang dimasukkan ke dalam pendekatan agama.

Selain itu, terdapat respons lainnya yang menunjukkan mengurangi food waste berkaitan dengan sikap empati konsumen terhadap petani serta dapat meringankan beban karyawan hotel untuk membersihkan sisa makanan. Terakhir, alasan lainnya yang menarik dalam hasil penelitian ini untuk dibahas adalah alasan "nanti nasinya menangis". Sebuah bentuk nilai yang lazim disampaikan oleh orang tua di Indonesia kepada anak agar tidak menyisakan makanan. Sedangkan responden yang memilih tidak bersedia dalam mengurangi food waste di resto hotel menyampaikan alasan menyisakan makanan dikarenakan rasa yang tidak disukai, proses pemasakan yang tidak sempurna, terlalu banyak mengambil porsi, dan menyisakan sedikit makanan tidak dianggap sebagai masalah.

Selanjutnya, responden diberikan beberapa pilihan metode resto hotel dalam mengurangi potensi timbulnya food waste. Hal ini dimaksudkan untuk menanyakan kepada responden metode yang sesuai dengan harapan untuk diterapkan oleh resto hotel. Selain itu, latar belakang pertanyaan ini diajukan kepada responden adalah karena pada dasarnya hotel perlu memastikan kenyamanan konsumen dalam pelayanannya. Lebih lanjut, jawaban dari pertanyaan bertujuan untuk memberikan gambaran kepada konsumen dan produsen bahwa food waste menjadi tanggung jawab bersama. Metode yang dipilih oleh konsumen ditampilkan pada Gambar 5. Hasil analisis mengungkapkan bahwa sebanyak 30 persen partisipan memilih pemasangan poster imbauan mengenai food waste diikuti oleh pengurangan ukuran alat makan dari restoran.
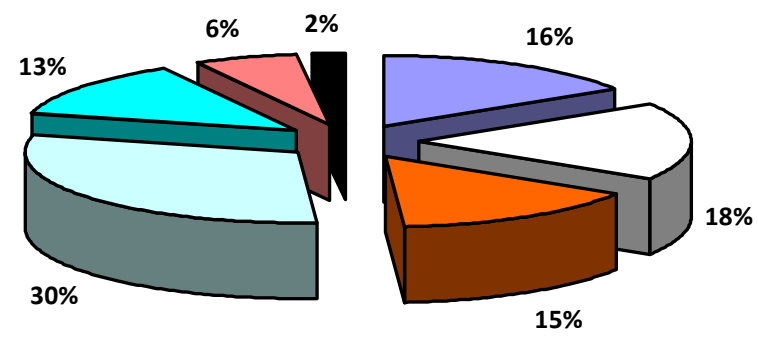
Memberikan denda bagi yang tidak
menghabiskan makanan

口Mengurangi ukuran alat makan (piring, mangkuk, gelas) menjadi lebih kecil

口Memasang pengumuman jumlah food waste di hari sebelumnya

$\square$ Memasang poster himbauan tentang food waste di resto hotel

$\square$ Membuat tester makanan

口Mengurangi jensi menu makanan

Lainnya

\section{Gambar 5 Metode mengurangi food waste}

Alasan selanjutnya yang dipilih adalah penerapan denda bagi yang tidak menghabiskan makanan (16\%) dan mengumumkan jumlah food waste di hari sebelumnya. Sedangkan beberapa metode lainnya (2\%) sebagai bahan pertimbangan yang ditambahkan dari responden meliputi memberikan keterangan mengenai tingkat keasaman atau pedas pada hidangan, pengaturan porsi oleh pramusaji, serta pengurangan volume penyajian. Selain itu, responden juga menambahkan berbagai media lainnya serta konten yang dapat digunakan dalam menghimbau konsumen terkait isu food waste mulai dari melalui video, pada voucher sarapan, dan meja, hingga memberikan gambaran proses makanan tercipta.

\section{Pengetahuan Objektif Food Waste pada Pengunjung Hotel}

Pada bagian akhir kuesioner, pertanyaan merujuk pada tingkat pengetahuan responden mengenai food waste. Pertanyaan yang diajukan pada survei untuk mengetahui tingkat pengetahuan responden merupakan pernyataan yang mendasar mengenai isu food waste. Pertanyaan diawali dengan pernah atau tidaknya responden mendengar isu food waste yang mendeskripsikan jangkauan informasi food waste kepada responden. Pertanyaan mengenai pengetahuan objektif food waste 
hanya dilanjutkan apabila responden menjawab "Ya".

Lebih lanjut, sebelum masuk ke pertanyaan selanjutnya terkait pengetahuan objektif, responden menjawab bahwa media sosial (Medsos) merupakan media yang paling banyak memberikan informasi terkait dengan food waste (32\%). Tingkat pengetahuan konsumen kemudian digali lebih dalam dengan mengajukan beberapa pertanyaan terkait pengetahuan arti food waste, food waste merupakan isu global, dan pengelolaan food waste yang dipayungi oleh SDGs serta fakta mengenai food waste di Indonesia. Rata-rata jawaban responden mengenai pengetahuan objektif food waste terdapat pada Tabel 2.

Dari seluruh responden (363 responden), sebanyak 66 persen (240 responden) pernah mendengar isu food waste. Berdasarkan enam pertanyaan yang diajukan, 227 responden sudah mengetahui arti food waste sebelum mengisi kuesioner yang diberikan. Terdapat penurunan pengetahuan responden seiring pertanyaan yang lebih mendalam, bahkan kurang dari 20 persen dari total responden survei (53 responden) yang mengetahui peringkat negara Indonesia sebagai penyumbang food waste kedua terbesar. Namun, angka rata-rata kembali meningkat pada pertanyaan terkait dengan estimasi sumbangan food waste dari negara Indonesia serta pemanfaatan food waste. Hal ini dapat disebabkan oleh fokus dari informasi yang diterima oleh responden terkait dengan food waste.

Tabel 2 Distribusi jawaban pengetahuan objektif

\begin{tabular}{lcr}
\hline $\begin{array}{l}\text { Pertanyaan pengetahuan objektif } \\
\text { food waste }\end{array}$ & $\mathrm{N}^{*}$ & $\begin{array}{r}\text { Rata- } \\
\text { rata } \pm \\
\text { SD }\end{array}$ \\
\hline P1: Mengetahui arti food waste & 227 & $\begin{array}{r}0,95 \pm \\
0,23\end{array}$ \\
P2: Mengetahui food waste isu & 208 & $0,87 \pm$ \\
global & & 0,34 \\
P3: Mengetahui food waste & 73 & $0,3 \pm$ \\
dipayungi pengelolaannya oleh & & 0,46 \\
SDG & & \\
P4: Mengetahui Indonesia negara & 53 & $0,22 \pm$ \\
kedua terbesar penyumbang food & & 0,41 \\
waste & & \\
P5: Mengetahui estimasi satu & 112 & $0,47 \pm$ \\
orang menyumbang 300 kg food & & 0,5 \\
waste per tahunnya & & \\
$\begin{array}{l}\text { P6: Mengetahui food waste dapat } \\
\text { dimanfaatkan kembali }\end{array}$ & & $0,8 \pm 0,4$ \\
\end{tabular}

Keterangan: $\mathrm{N}^{*}=240$ yang menjawab pernah mendengar food waste dari 363 responden survei
Pertanyaan mengenai pengetahuan diakhiri oleh sejauh mana responden mengetahui berbagai produk pemanfaatan food waste. Pertanyaan ini hanya dapat diakses oleh responden yang mengetahui bahwa food waste dapat dimanfaatkan. Pemanfaatan food waste diantaranya diolah menjadi makanan kembali (bukan berasal dari piring konsumen), pakan, kompos, dan sumber energi. Respons terbanyak yang didapatkan secara berurutan adalah dimanfaatkan menjadi kompos, pakan, sumber energi, dan diolah kembali menjadi makanan.

\section{Upaya Pengelolaan Food Waste oleh Resto Hotel}

Selain hasil survei, wawancara dilakukan pada manajemen resto hotel untuk mengetahui upaya pencegahan dan pengelolaan food waste yang timbul oleh para konsumennya. Resto hotel hanya menyediakan menu masakan Indonesia berdasarkan hasil observasi selama pengambilan data. Konfirmasi dari pihak hotel terkait dengan menu yang dipilih adalah telah dilakukannya evaluasi terhadap menu yang lebih disukai oleh konsumen.

Penentuan menu makanan juga didasari oleh tujuan pengunjung hotel serta kelas pengunjung. Diketahui oleh manajemen hotel bahwa tujuan pengunjung Hotel Amaris mayoritas hanya singgah untuk berlibur ke destinasi wisata, bukan untuk berlibur di hotel. Sedangkan untuk kelas pengunjung pada Hotel Amaris adalah kelas menengah ke bawah. Sebagai pertimbangan, staf bagian dapur belum pernah mengetahui bahwa isu food waste merupakan masalah global, namun telah mengetahui bahwa pengurangannya dapat memberikan keuntungan secara ekonomi.

Hotel sangat terbuka terhadap inovasi pengelolaan food waste dan masukan dari hasil survei yang diajukan kepada konsumen resto hotel. Pemasangan imbauan mengenai food waste merupakan metode yang dapat diterima oleh hotel sejauh tidak mengurangi kenyamanan pada pengunjung hotel. Adapun penggantian ukuran alat makan menjadi lebih kecil belum menjadi pilihan manajemen hotel untuk mencegah timbulnya food waste atas alasan biaya yang dikeluarkan. Namun, intervensi yang direncanakan akan dilakukan setelah pandemi adalah pengaturan penyajian. Hal ini didasari oleh observasi hotel terhadap konsumen yang cenderung tidak berlebihan dalam mengambil porsi ketika penyajian setengah dari wadah penyajian. 


\section{PEMBAHASAN}

Hasil studi menunjukkan rata-rata timbulan food waste di akhir pekan lebih banyak dibanding dengan hari biasa selaras dengan jumlah konsumen. Hal ini juga dinyatakan oleh Brigita dan Rahardyan (2013) bahwa jumlah pengunjung dan jenis makanan memengaruhi timbulan food waste di resto hotel. Pada penelitian ini ditemukan karbohidrat berupa nasi dan turunannya merupakan komponen yang paling banyak terbuang di resto hotel. Bubur pada penelitian ini menyumbang berat yang paling dominan dibandingkan dengan menu lainnya. Hal ini didukung oleh penelitian Lin (2016) bahwa kadar air pada timbulan food waste relatif menyumbang berat yang tinggi. Temuan komposisi ini selaras dengan penelitian yang dilakukan oleh Wulansari, Ekayani, dan Karlinasari (2019) yang menyatakan bahwa nasi merupakan komponen makanan terbesar yang terbuang di warung makan. Selain itu berdasarkan penelitian di beberapa negara seperti Cina, Malaysia dan Amerika ditemukan bahwa komponen karbohidrat yang menjadi makanan pokok, antara lain gandum, nasi, mi, dan roti canai merupakan komponen makanan terbesar yang terbuang (Chua et al., 2019; Kuo \& Shih, 2016; Spiker et al., 2017). Hal ini menunjukkan bahwa konsumen cenderung menyisakan komponen karbohidrat. Selain itu, cara penyajian dengan konsep prasmanan memberikan keleluasaan bagi konsumen untuk mengambil porsi yang diinginkan. Temuan ini selaras dengan Anriany dan Martianto (2013) yang menyatakan bahwa sisa nasi lebih banyak ditemukan pada rumah makan yang menyajikan nasi di wadah dibandingkan dengan yang ditakar.

Adapun temuan yang menarik adalah roti yang gosong ditemukan hampir setiap hari selama pengambilan data. Hal ini berulang kali terjadi karena kurangnya pengetahuan ataupun keterampilan konsumen terhadap alat pembakar yang disediakan. Tata cara penggunaan alat pembakar roti sudah disediakan dengan pertimbangan terbatasnya SDM dari hotel untuk membantu. Dalam hubungan ini, Silvennoinen et al. (2020) menyatakan bahwa kesalahan proses pemasakan seperti masakan yang gosong kerap kali menjadi tanggung jawab koki dan dapat dihindari dengan memastikan pengalaman dan kemampuan memasak yang professional. Namun, pada penelitian ini ditemukan bahwa ketidaktahuan konsumen dalam mengoperasikan alat pembakar serta keterbatasan jumlah petugas hotel menjadi faktor penyebab food waste.
Survei daring yang dilaksanakan kepada kelompok mahasiswa dan pekerja diisi oleh 56 persen milenial. Kelompok milenial menjadi target responden dan dianggap relevan dengan isu food waste (Fox et al., 2018). Saat ini, Generasi Milenial berperan sebagai kontributor tertinggi penghasil food waste namun pada saat yang bersamaan juga mendukung gerakan makanan (food movement) yang didalamnya mengusung aspek etika dalam produksi makanan (Ristino, 2013). Selain itu, pengambilan data terhadap konsumen relevan dengan pernyataan Heikkilä et al. (2016) yang menyebutkan, konsumen merupakan salah satu penyumbang food waste, khususnya pada sisa konsumsi di piring. Hal ini disebabkan oleh beberapa faktor diantaranya kualitas atau rasa yang kurang baik, rasa makanan yang berbeda dari ekspektasi konsumen, atau terlalu banyak mengambil porsi. Lebih lanjut, kajian yang dilakukan oleh Heikkilä et al. (2016) selaras dengan hasil penelitian ini yang menunjukkan bahwa dua alasan utama timbulnya food waste pada konsumen yaitu dikarenakan rasa makanan yang kurang cocok dan terlalu banyak mengambil porsi makanan.

Salah satu alasan yang tidak dapat dihindari dalam menyisakan makanan adalah menghindari kandungan alergen. Pihak manajemen hotel perlu memberikan perhatian khusus pada alasan ini karena permasalahan yang dapat timbul bukan hanya mengenai lingkungan tetapi juga kesehatan konsumen. Pencantuman kandungan alergen dan reaksi alergi pada makanan akan membantu konsumen untuk memilih apa yang dibelinya (Upadhyaya, 2019). Peraturan ini pada umumnya belum ditemukan pada restoran hotel dan lebih sering tercantum pada makanan dalam kemasan.

Sebagai upaya pencegahan food waste, pendekatan yang dipilih dalam mengurangi food waste juga ditanyakan pada responden. Berdasarkan hasil survei, didapatkan pendekatan yang paling banyak dipilih adalah pendekatan ekonomi walaupun nilainya tidak jauh berbeda dengan pendekatan agama. Selaras dengan Neff, Spiker, dan Truant (2015) yang menyatakan bahwa pendekatan ekonomi memiliki dampak yang lebih personal untuk memotivasi dalam mengurangi food waste karena berkaitan langsung dengan pengeluaran konsumen. Sedangkan pendekatan norma dan agama menjadi bentuk kampanye yang dapat membangun ketahanan pangan yang kuat dan berkelanjutan serta menghambat food waste behavior (Kariyasa \& Suryana, 2012). Pernyataan lainnya seperti "nanti nasinya 
menangis" merupakan pendekatan norma yang sering ditemukan disampaikan orang tua kepada anak, sebagaimana hasil penelitian Prasetyo dan Djuwita (2020) bahwa orang yang paling berpengaruh bagi informan dalam menghindari food waste adalah orang tuanya. Pentingnya internalisasi nilai menghindari food waste kepada anak dapat membantu menanamkan nilai yang tetap diingat hingga dewasa.

Pendekatan lingkungan bagi responden bukan merupakan alasan utama dalam menghindari food waste. Hasil ini berbeda dengan hasil penelitian Lavén (2017) yang mengungkapkan pendekatan lingkungan lebih banyak dipilih, namun selaras dengan Schanes, Dobernig, dan Gözet (2018) yang menemukan bahwa motif pendekatan lingkungan menjadi motif minor dibandingkan dengan pendekatan ekonomi. Bila dilihat dari aspek lingkungan, timbulan food waste oleh konsumen resto hotel merupakan bentuk dari pemborosan makanan yang berkontribusi pada lingkungan. Pada setiap hidangan yang terbuang terdapat sumber daya yang hilang yang digunakan dalam proses pemasakan. Pernyataan ini sama dengan penelitian yang dilakukan oleh Usubiaga, Butnar, dan Schepelmann (2017) bahwa pengurangan setengah food waste secara global setidaknya mengurangi 2 sampai 7 persen kategori sumber daya yang digunakan dalam memproduksinya.

Pada bagian terakhir, responden diberikan pilihan metode pengurangan food waste yang sudah diterapkan berdasarkan penelitian terdahulu. Metode yang paling banyak dipilih adalah pemasangan imbauan mengenai food waste dan pengurangan ukuran pada alat makan. Beberapa penelitian terdahulu melakukan intervensi perancangan arsitektur pilihan untuk mengurangi timbulan food waste dengan mengatur ukuran piring pada konsep prasmanan. Ukuran alat makan di resto hotel pada umumnya memiliki diameter yang lebih besar dibandingkan dengan ukuran yang biasa digunakan oleh konsumen. Wansink dan van Ittersum (2013) menjelaskan bahwa terdapat bias dalam menentukan porsi makanan apabila menggunakan piring berdiameter besar. Sedangkan penelitian Kalbekken dan Sælen (2013) membuktikan bahwa pengurangan ukuran piring di resto hotel terbukti mengurangi food waste hingga 19,50 persen. Sebagai catatan, tidak semua intervensi ukuran alat makan selalu memiliki korelasi dengan berkurangnya food waste seperti pada penelitian Kosīte et al. (2019).
Di sisi lain, intervensi dalam pengurangan ukuran alat makan memiliki tantangan bagi hotel dalam mengeluarkan biaya tambahan untuk mengganti alat makan. Maka dari itu, terdapat beberapa pilihan intervensi lainnya yang dapat menjadi alternatif bagi resto hotel untuk mengajak konsumen mengurangi food waste. Sebagaimana hasil wawancara adalah rencana intervensi pengurangan volume makanan pada wadah penyajian yang didasari oleh observasi internal manajemen hotel. Intervensi ini merupakan bentuk perancangan arsitektur pilihanuntuk mengubah atau menggiring perilaku (Thaler \& Sunstein, 2008) konsumen.

Penerapan denda bagi konsumen yang menyisakan makanan cukup banyak dipilih oleh responden. Metode penerapan denda bisa menjadi bentuk stimulus konsumen agar mengurangi food waste misalnya denda hitungan per gram bagi makanan yang disisakan oleh konsumen pada piring (Waarts et al., 2011). Namun, pada praktiknya denda jarang diberlakukan karena kurang sesuai dengan program restoran dalam meningkatkan loyalitas konsumen (Kuo \& Shih, 2016). Pilihan lainnya adalah pemberian hadiah sebagai bentuk penghargaan bagi konsumen yang mencegah timbulnya food waste. Metode ini dapat menjadi pengalaman pembelajaran bagi keluarga, khususnya yang mengikutsertakan anak sebagaimana yang dilakukan pada penelitian Dolnicar, Juvan, dan Grün (2020).

Hasil analisis statistik deskriptif menggambarkan sejauh mana pengetahuan objektif responden terhadap isu food waste. Berdasarkan hasil survei, hanya sebagian responden yang sudah pernah mendengar food waste. Adapun responden yang pernah mendengar isu food waste sebelumnya masih kurang mengetahui atau belum mendapatkan informasi terkait urgensi pengelolaan food waste serta kontribusi negara Indonesia sebagai penyumbang food waste di tingkat global. Pengujian tingkat pengetahuan konsumen diperlukan karena pengetahuan konsumen mengenai dampak food waste berpengaruh pada pengurangan timbulan food waste (Jereme et al., 2018). Selain itu, pengetahuan tentang lingkungan memiliki peran penting dalam pembentukan sikap yang lebih pro-lingkungan (Recker \& Saleem, 2014). Hasil ini selaras dengan Fox et al. (2018) yang menunjukkan bahwa tingkat pengetahuan mengenai isu food waste dinilai cukup tinggi pada responden yang berasal dari Indonesia, namun, tingkat pengetahuan belum selaras dengan pengetahuan mengenai perannya 
sebagai konsumen dalam pencegahan ataupun pengelolaan food waste.

Pengetahuan responden terkait pemanfaatan food waste menjadi penting untuk melihat sejauh mana responden mengetahui konsep pemulihan makanan. Pertanyaan ini sekaligus memberikan pengetahuan mengenai potensi dari nilai kehilangan food waste kepada responden. Pada penelitian food waste diartikan sebagai sisa konsumsi dari piring konsumen, maka dimungkinkan sebagian besar responden tidak memilih pilihan "pengolahan kembali menjadi makanan". Pemanfaatan yang paling banyak dipilih responden adalah kompos, yang mana sosialisasi mengenai pendauran sampah organik menjadi kompos sudah banyak dilakukan dibandingkan dengan produk lainnya. Apabila merujuk pada konsep pemulihan food waste oleh US EPA (2017), pengomposan food waste adalah pilihan kedua terakhir setelah dijadikan bahan pakan dan sumber energi. Selain itu, yang perlu dihindari adalah adanya anggapan bahwa menyisakan makanan tidak menjadi masalah karena dapat dikompos sebagaimana yang ditemukan pada penelitian Neff et al. (2015). Adapun penerapan pengomposan perlu mempertimbangkan aspek komposisinya untuk memastikan food waste dapat terdekomposisi dengan baik dalam kurun waktu tertentu serta tidak membahayakan lingkungan (Ayilara et al., 2020).

Saat ini, pencegahan timbulan food waste oleh manajemen hotel dilakukan dengan memilih menu yang lebih disukai oleh konsumen berdasarkan tujuan kunjungan dan latar belakang konsumen (finansial). Menu yang dipilih adalah menu Indonesia atau masakan lokal. Cara ini dapat mengurangi kemungkinan terbuangnya makanan karena menu makanan kurang dikenal dan rasanya tidak sesuai dengan ekspektasi konsumen, selaras dengan pernyataan Aschemann-Witzel et al. (2015). Selain itu, manajemen hotel juga dapat mengevaluasi pemilihan menu berdasarkan food waste yang tersisa di piring konsumen. Observasi jumlah dan jenis sisa makanan di piring konsumen dapat menghindari makanan yang terbuang selanjutnya (Drewitt, 2013). Pencanangan pengaturan penyajian makanandirancang berdasarkan observasi hotel. Pada penelitian Papargyropoulou et al. (2014) juga dilakukan observasi terhadap pengambilan porsi makanan oleh konsumen pada restoran dengan konsep prasmanan. Pada konsep ini dimungkinkan konsumen untuk mengambil porsi yang terlalu banyak dan menyisakan sejumlah makanan pada piring sebelum akhirnya mengambil piring lain. Siklus yang diulang beberapa kali hingga konsep ini menjadi salah satu sumber timbulan food waste.

Pentingnya melakukan pengurangan food waste dari sumber sebagaimana dijelaskan pada konsep Food Recovery Hierarchy (US EPA, 2017) memiliki tantangan yang besar namun memiliki dampak yang lebih signifikan. Sahakian et al. (2020) menyatakan bahwa pengurangan food waste dari sumber perlu banyak dilakukan dibandingkan dengan pengelolaan timbulan food waste melalui pendauran ulang. Untuk itu dibutuhkan kerja sama dari berbagai pihak baik dari pihak konsumen maupun manajemen resto hotel.

Pada penelitian ini, metode yang paling banyak dipilih oleh responden selaras dengan metode yang dapat diterima oleh hotel contoh adalah pemasangan imbauan resto mengenai informasi pengurangan food waste. Pendekatan yang paling banyak dipilih adalah pendekatan ekonomi dan agama. Adapun isu food waste baru diketahui sebagian responden. Sebagai tambahan, informasi food waste diakui lebih banyak diperoleh dari media sosial. Beberapa temuan penelitian ini dapat menjadi bahan masukan kepada pihak pemangku kebijakan serta hotel untuk mendorong tingkat pengetahuan konsumen mengenai food waste sebagai upaya pengurangan food waste pada resto hotel, dengan memberikan informasi terkait isu food waste melalui pemasangan imbauan dan media sosial.

\section{SIMPULAN DAN SARAN}

Hasil studimenunjukkan bahwa jumlah food waste dipengaruhi oleh jumlah konsumen. Faktor yang mendorong timbulnya food waste dari konsumen adalah rasa makanan yang kurang cocok dan pengambilan porsi yang terlalu banyak. Pendekatan yang diyakini dapat lebih mencegah timbulnya food waste adalah pendekatan ekonomi dan nilai internalisasi agama dibandingkan dengan pendekatan lingkungan. Pemasangan imbauan pengurangan food waste merupakan metode yang paling banyak dipilih oleh responden untuk diterapkan oleh resto hotel dalam mengurangi food waste. Isu food waste baru diketahui sebagian dari responden penelitian.

Penelitian ini tidak luput dari beberapa keterbatasan. Pertama, penelitian terbatas pada contoh data food waste di Hotel berbintang dua yang tidak dapat menggambarkan tren food waste pada seluruh tingkat bintang Hotel. Kedua, fokus bahasannya 
pada pengetahuan konsumen sebagai salah satu faktor yang memengaruhi perilaku konsumen. Terdapat variabel lainnya selain pengetahuan yang dapat memengaruhi perilaku konsumen dalam menyisakan makanan. Selain itu penelitian ini belum melihat hubungan antara pengetahuan konsumen mengenai food waste dengan sumbangan timbulan food waste secara aktual. Penelitian selanjutnya dapat menguji seberapa besar pengaruh tingkat pengetahuan dan faktor lainnya terhadap timbulnya food waste dengan skala statistik yang lebih sesuai. Hasil studi dapat menjadi dasar penelitian lanjutan dengan metode intervensi peningkatan pengetahuan bagi konsumen resto hotel dan pertimbangan bagi pemangku kebijakan dalam meningkatkan pengetahuan konsumen untuk mencegah food waste yang disesuaikan dengan kapasitas hotel.

\section{UCAPAN TERIMAKASIH}

Peneliti ingin mengucapkan terima kasih kepada Manajemen Hotel Amaris Setiabudhi Bandung atas kesempatan dan bantuan dalam pengambilan data contoh food waste serta kepada seluruh responden yang bersedia secara sukarela mengisi survei penelitian.

\section{DAFTAR PUSTAKA}

Aktas, E., Sahin, H., Topaloglu, Z., Oledinma, A., Huda, A. K. S., Irani, Z., Sharif, A. M., van't Wout, T., \& Kamrava, M. (2018). A consumer behavioural approach to food waste. Journal of Enterprise Information Management, 31(5), 658-673. doi:10.1108/JEIM-03-2018-0051.

Anriany, D., \& Martianto, D. (2013). Estimasi sisa nasi konsumen di beberapa jenis rumah makan di Kota Bogor. Jurnal Gizi dan Pangan, 8(1), 33-38.

Aschemann-Witzel, J., de Hooge, I., Amani, P., Bech-Larsen, T., \& Oostindjer, M. (2015). Consumer-related food waste: Causes and potential for action. Sustainability, 7(Review), 6457-6477. doi:10.3390/su7066457.

Ayilara, M. S., Olanrewaju, O.S., Babalola O. O., \& Odeyemi, O. (2020). Waste management through composting: Challenges and potentials. Sustainability, 12(Review), 1-23. doi:10.3390/su12114456.

[BPS Kota Bandung] Badan Pusat Statistik Kota Bandung. (2017). Data Produksi
Sampah Menurut Jenisnya Tahun 2017. Bandung, ID: BPS.

Brigita, G., \& Rahardyan, B. (2013). Analisa pengelolaan sampah makanan di Kota Bandung. Jurnal Teknik Lingkungan, 19(1), 34-45.

[BSN] Badan Standardisasi Nasional. (1994). Metode Pengambilan dan Pengukuran Contoh Timbulan dan Komposisi Sampah Perkotaan SNI 19-3964-1994. Jakarta, ID: BSN.

Chua, G. K., Tan, F. H. Y., Chew, F. N., \& Mohd-Hairul, A. R. (2019). Nutrients content of food wastes from different sources and its pre-treatment. In AIP Conference Proceedings, 2124(1).

Dolnicar, S., Juvan, E., \& Grün, B. (2020). Reducing plate waste of families at hotel buffets- a quasi- experimental study. Tourism Management, 80(10),1-12. doi:10.1016/j.tourman.2020.104103.

Drewitt, T. (2013). Food waste prevention in quick service restaurant (Tesis). Lund, SE: University Lund.

[FAO] Food Agriculture Organization of the United Nations. (2011). Global Food Losses and Food Waste- Extent, Causes and Prevention. Study conducted for the International Congress Save Food at Interpack 2011, Düsseldorf, Germany. Retrieved from http://www.fao.org/3/mb060e/mb060e.pdf.

Fox, D., Ioannidi, E., Sun, Y. T., Jape, V. W., Bawono, W. R., Zhang, S., \& Perez-Cueto, F. J. A. (2018). Consumers with high education levels belonging to the millennial generation from Denmark, Greece, Indonesia and Taiwan differ in the level of knowledge on food waste. International Journal of Gastronomy and Food Sciences, 11, 49-54. doi:10.1016/j.ijgfs.2017.11.005.

Heikkilä, L., Reinikainen, A., Katajajuuri, J.M., Silvennoinen, K., \& Hartikainen, H. (2016). Elements effecting food waste in the food service sector. Waste Management, 56(2016), 446-453. doi: 10.1016/j.wasman.2016.06.019.

Jereme I. A., Siwar, A., Begum, R. A., Talib, B. A., \& Choy, E. A. (2018). Analysis of household food waste reduction towards sustainable food management in Malaysia. Journals of Solid Waste Technology and Management, 44(1), 86-96. 
Kalbekken, S., \& Sælen, H. (2013). 'Nudging' hotel guests to reduce food waste as a win-win environmenta measures. Economic Letters, 119(2013), 325-327. doi:10.1016/j.econlet. 2013.03.019.

Kariyasa, K., \& Suryana, A. (2012). Memperkuat ketahanan pangan melalui pengurangan pangan. Analisis Kebijakan Pertanian 10(3),269-288.

Kosīte, D., König, L.M., De-loyde, K., Lee, I., Pechey, E., Clarke, N., ........Hollands, G. J. (2019). Plate size and food consumption: A pre-registered experimental study in a general population sample. International Journal of Behavioural Nutrition and Physical Activity, 16(75), 1-9. doi:10.1186/s12966-0190826-1.

Kuo, C., \& Shih, Y. (2016). Gender differences in the effects of education and coercion on reducing buffet plate waste. Journal of Foodservice Bussiness Research, 19(3),113. doi: $10.1080 / 15378020$ .2016 .11758986

Lavén, J. (2017). Consumers' food waste behaviour in restaurant (Tesis). Gothenburg, SE: University of Gothenburg.

Lin, S. (2016). Waste stream analysis of allyou-can-eat buffet restaurant in tourist hotels- the study of the influence of current restaurant practices on their foodservice waste. European Journal of Hospitality and Tourism Research, 4(3),1-27.

Neff, R. A., Spiker, M. L., \& Truant, P. L. (2015). Wasted food: U.S consumer' reported awareness, attittude and behaviors. Plos One, 10, 1-16. doi:10.1371/journal.pone.0127881.

Papargyropoulou, E., Steinberger, J. K., Wright, N., Lozano, R., Padfield, R., \& Ujang. (2014). Patterns and causes of food waste in the hospitality and food service sector: Food prevention insights from Malaysia. Sustainability, 76(2014), 106-115. doi:10.3390/su11216016.

Pemerintah Provinsi Jawa Barat. (2018). Indeks pariwisata Kota Bandung salah satu tertinggi di Indonesia. Retrieved from https://jabarprov.go.id/index.php/news/268 81/2018/01/12/.

Prasetyo, D. T., \& Djuwita, R. (2020). Penggunaan theory planned behaviour dalam menganalisis faktorfaktor yang memengaruhi food waste behaviour pada dosen. Jurnal IImu Keluarga dan Konsumen, 13(3), 277-288. doi:10.24156/jikk.2020.13.3.277.

Recker, A., \& Saleem, B. (2014). The effect of consumer knowledge and values on purchase intentions a quantitative study of organic personal care products among German female consumers (Tesis). Umeå, SE: Umeå School Business and Economics.

Ristino, L. (2013). Back to the new millenials: Millenials and the sustainable food movement. Vermont Journal of Environmental Law, 15(37-13), 1-30.

Sahakian, M., Shenoy, M., Soma, M., Watabe, A., Yagasa, R., Premakumara, D. G. J.,...Saloma, C. (2020). Apprehending food waste in Asia: Policies, practices, and promising trends. In Routledge Handbook of Food Waste). New York, NY: Taylor and Francis Group.

Schanes, K., Dobernig, K., \& Gözet, B. (2018). Food waste matters - A systematic review of household food waste practices and their policy implications. Journal of Cleaner Production, 182(2018), 978-991. doi:10.1016/j.clepro.2018.02.030.

Silvennoinen, K., Nisonen, S., Pietiläinen, O., Reynolds, C., Soma, T., Spring, C., \& Lazell, J. (2020). Food waste in the service sector: Key concept, measurement methods, and best practices. In Routledge Handbook of Food Waste. New York, NY: Taylor and Francis Group.

Stancu, V., Haugaard, P., \& Lähteenmäki, L. (2016). Determinants of consumer food waste behaviour: Two routes to food waste. Appetite, 96(2016), 7-17. doi:10.106/j.appet.2015.08.025.

Spiker, M. L., Hazel, A. B., Siddiqi, S. M., \& Neff, R. A. (2017). Wasted food, wasted nutrients: Nutrient loss from wasted food in the United States and comparison to gaps in dietary intake. Journal of the Academy of Nutrition and Dietetics, 117(7), 10311040. doi:10.1016/j.jand.201703.015.

Thaler, R., \& Sunstein, C. (2008). Nudge: Improving decisions about health, wealth and happiness. New Haven, US: Yale University Press.

Upadhyaya, A. (2019). An analysis of food waste in Germany (Tesis). Nürnberg, GE: Friedrich-Alexander Universität, Erlangen.

[US EPA] United State Environmental Protection Agency. (2017). Sustainable 
Management of Food. Retrieved from https://www.epa.gov/sustainablemanagement-food/sustainablemanagement-food-basics.

Usubiaga, A., Butnar, I., \& Schepelmann, P. (2018). Wasting food wasting resources potential environmental savings through food waste production. Journal of Industrial Ecology, 22(3), 574-584. doi:10.1111/jiec.12695.

Wansink, B., \& van Ittersum K. (2013). Portion size me: Plate-size induced consumption norms and win-win solution for reducing food intake and waste. Journal of
Experimental Psychology: Applied, 19(4), 320-332.

Waarts, Y., Eppink, M., Oosterkamp, E., Hiller, S., van der Sluis, A., \& Timmermans, T. (2011). Reducing food waste obstacles experienced in legislation and regulations (LEI Reports). Wageningen, NL: Food and Biobased Research part of Wageningen UR.

Wulansari, D., Ekayani. M., \& Karlinasari. (2019). Kajian timbulan sampah makanan warung makan. Ecotrophic: Jurnal IImu Lingkungan, 13(2),125-134. 